medRxiv preprint doi: https://doi.org/10.1101/2021.05.27.21257929; this version posted June 1, 2021. The copyright holder for this preprint (which was not certified by peer review) is the author/funder, who has granted medRxiv a license to display the preprint in perpetuity.

All rights reserved. No reuse allowed without permission.

\title{
Impact of vaccination and undetected cases on the COVID-19 pandemic dynamics in Qatar in 2021
}

\author{
Igor Nesteruk \\ Institute of Hydromechanics, National Academy of Sciences of Ukraine \\ National Technical University of Ukraine “Igor Sikorsky Kyiv Polytechnic Institute”. \\ inesteruk@yahoo.com
}

\begin{abstract}
The third COVID-19 pandemic wave in Qatar was simulated with the use of the generalized SIR-model and the accumulated number of cases reported by Johns Hopkins University for the period: April 25 May 8, 2021. Comparison with the SIR-curves calculated before for the second wave showed that the effect of mass vaccination is not evident during 4 months after its onset in December 2020. Additional simulations have demonstrated that many COVID-19 cases are not detected. The real accumulated number of cases can exceed the laboratory-confirmed one more than 5 times. This fact drastically increases the probability of meeting an infectious person and the epidemic duration.
\end{abstract}

Keywords: COVID-19 pandemic, vaccination efficiency, epidemic dynamics in Qatar, mathematical modeling of infection diseases, SIR model, parameter identification, statistical methods.

\section{Introduction}

The COVID-19 pandemic dynamics in Qatar was simulated with the use of SEIR-model (susceptible-exposed-infected-removed) [1] and SEIRD-model (susceptible-exposed-infected-removeddead) [2]. Some recent SIR-simulations [3] were based on the dataset about the number of cases in December 2020, when the mass vaccination started in this country. In this study we will use the information about the accumulated number of cases from COVID-19 Data Repository by the Center for Systems Science and Engineering (CSSE) at Johns Hopkins University (JHU), [4]. We will analyze the recent epidemic dynamics in Qatar and make some predictions taking into account the incompleteness of the statistical information with the use of method proposed in [5].

\section{Data}

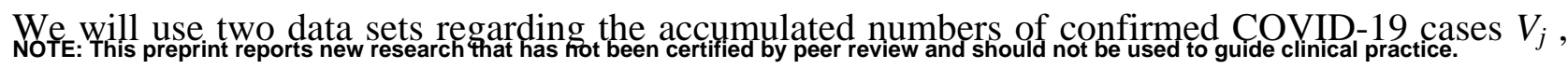
number of vaccinated people $S_{j}$ and number of vaccinations $Q_{j}$ in Qatar from JHU, [4]. These values and corresponding moments of time $t_{j}$ (measured in days) are shown in Table 1. For SIR-simulations 
medRxiv preprint doi: https://doi.org/10.1101/2021.05.27.21257929; this version posted June 1, 2021. The copyright holder for this preprint (which was not certified by peer review) is the author/funder, who has granted medRxiv a license to display the preprint in perpetuity. All rights reserved. No reuse allowed without permission.

we have used the values of $V_{j}$ and $t_{j}$ corresponding to the time period $T_{c 3}$ : April 25 - May 8, 2021 during the third epidemic wave in Qatar. Other values presented in Table 1 and datasets available in [3] were used only for comparisons and verifications of the calculations.

\begin{tabular}{|c|c|c|c|c|c|c|c|c|}
\hline $\begin{array}{l}\text { Day in } \\
\text { Febru- } \\
\text { ary } \\
\text { and } \\
\text { March } \\
2021\end{array}$ & $\begin{array}{c}\text { Number } \\
\text { of cases, } \\
V_{j}\end{array}$ & $\begin{array}{c}\text { Day in } \\
\text { March } \\
\text { and } \\
\text { April } \\
2021\end{array}$ & $\begin{array}{c}\text { Number } \\
\text { of cases } \\
V_{j}\end{array}$ & $\begin{array}{c}\text { Number } \\
\text { of vacci- } \\
\text { nations, } \\
Q_{j}\end{array}$ & $\begin{array}{c}\text { Day in } \\
\text { April } \\
\text { and May } \\
2021\end{array}$ & $\begin{array}{c}\text { Number } \\
\text { of } \\
\text { cases, } \\
V_{j}\end{array}$ & $\begin{array}{c}\text { Number } \\
\text { of vacci- } \\
\text { nations, } \\
Q_{j}\end{array}$ & $\begin{array}{c}\text { Number of } \\
\text { vaccinated } \\
\text { people } \\
S_{j}\end{array}$ \\
\hline 21 & 160426 & 24 & 175332 & 658325 & 24 & 201496 & 1394781 & - \\
\hline 22 & 160889 & 25 & 175919 & 679278 & 25 & 202201 & 1415761 & - \\
\hline 23 & 161344 & 26 & 176521 & 701943 & 26 & 202904 & 1442708 & - \\
\hline 24 & 161803 & 27 & 177135 & 721236 & 27 & 203599 & 1469633 & - \\
\hline 25 & 162268 & 28 & 177774 & 740309 & 28 & 204289 & 1496833 & - \\
\hline 26 & 162737 & 29 & 178464 & 765110 & 29 & 204976 & 1526775 & 971973 \\
\hline 27 & 163197 & 30 & 179184 & 790676 & 30 & 205652 & 1556203 & 989627 \\
\hline 28 & 163664 & 31 & 179964 & 816484 & 1 & 206302 & 1579002 & 1002748 \\
\hline 1 & 164137 & 1 & 180804 & 842000 & 2 & 206948 & 1603913 & 1017019 \\
\hline 2 & 164600 & 2 & 181678 & 867209 & 3 & 207592 & 1635398 & 1031300 \\
\hline 3 & 165071 & 3 & 182548 & 889202 & 4 & 208232 & 1670911 & 1047196 \\
\hline 4 & 165546 & 4 & 183424 & 910851 & 5 & 208877 & 1701914 & 1064294 \\
\hline 5 & 166015 & 5 & 184334 & 934843 & 6 & 209470 & 1732471 & 1080415 \\
\hline 6 & 166475 & 6 & 185261 & 961555 & 7 & 210070 & 1762545 & 1094976 \\
\hline 7 & 166949 & 7 & 186201 & 987673 & 8 & 210603 & 1787160 & 1103747 \\
\hline 8 & 167417 & 8 & 187150 & 1012716 & 9 & 210992 & 1813240 & 1115842 \\
\hline 9 & 167888 & 9 & 188100 & 1041632 & 10 & 211389 & 1844658 & 1127091 \\
\hline 10 & 168361 & 10 & 189064 & 1062250 & 11 & 211732 & 1876178 & 1137843 \\
\hline 11 & 168829 & 11 & 190025 & 1079776 & 12 & 212124 & 1911663 & 1149854 \\
\hline 12 & 169284 & 12 & 190998 & 1104726 & 13 & 212423 & 1944628 & 1160213 \\
\hline 13 & 169767 & 13 & 191979 & 1131631 & 14 & 212667 & 1976748 & 1168975 \\
\hline 14 & 170252 & 14 & 192963 & 1159479 & 15 & 212927 & 2002018 & 1177725 \\
\hline 15 & 170733 & 15 & 193952 & 1183191 & 16 & 213183 & 2035475 & 1190700 \\
\hline 16 & 171212 & 16 & 194930 & 1209648 & 17 & 213485 & 2073354 & 1206737 \\
\hline 17 & 171701 & 17 & 195757 & 1225110 & 18 & 213855 & 2109980 & 1221996 \\
\hline 18 & 172200 & 18 & 196580 & 1248229 & 19 & 214150 & 2150749 & 1240202 \\
\hline 19 & 172697 & 19 & 197476 & 1271478 & 20 & 214463 & 2190807 & 1261828 \\
\hline 20 & 173206 & 20 & 198361 & 1296520 & 21 & 214830 & - & - \\
\hline 21 & 173709 & 21 & 199180 & 1320866 & 22 & - & - & - \\
\hline 22 & 174228 & 22 & 199980 & 1345423 & 23 & - & - & - \\
\hline 23 & 174762 & 23 & 200778 & 1372396 & 24 & - & - & - \\
\hline
\end{tabular}

Table 1. Cumulative numbers for Qatar from [4]. The laboratory-confirmed Covid-19 cases $V_{j}$, number of vaccinations $Q_{j}$, the number of vaccinated people $S_{j}$, and corresponding moments of time. 
medRxiv preprint doi: https://doi.org/10.1101/2021.05.27.21257929; this version posted June 1, 2021. The copyright holder for this preprint (which was not certified by peer review) is the author/funder, who has granted medRxiv a license to display the preprint in perpetuity. All rights reserved. No reuse allowed without permission.

\section{Generalized SIR model and parameter identification procedure}

The classical SIR model for an infectious disease [6-8] was generalized in [5, 9] to simulate different epidemic waves. We suppose that the SIR model parameters are constant for every epidemic wave, i.e. for the time periods: $t_{i}^{*} \leq t \leq t_{i+1}^{*}, i=1,2,3, \ldots$. Then for every wave we can use the equations, similar to [6-8]:

$$
\begin{gathered}
\frac{d S}{d t}=-\alpha_{i} S I, \\
\frac{d I}{d t}=\alpha_{i} S I-\rho_{i} I, \\
\frac{d R}{d t}=\rho_{i} I .
\end{gathered}
$$

Here $S$ is the number of susceptible persons (who are sensitive to the pathogen and not protected); $I$ is the number of infectious persons (who are sick and spread the infection ); and $R$ is the number of removed persons (who no longer spread the infection). It must be noted that $I(t)$ is not the number of active cases. People can be ill (among active cases), but isolated. In means, that they don't spread the infection anymore. There are many people spreading the infection but not tested and registered as active cases. The use of number of active cases as $I(t)$ in some papers a principal mistake which may lead to incorrect results. Parameters $\alpha_{i}$ and $\rho_{i}$ are supposed to be constant for every epidemic wave.

To determine the initial conditions for the set of equations (1)-(3), let us suppose that at the beginning of every epidemic wave $t_{i}^{*}$ :

$$
\begin{gathered}
I\left(t_{i}^{*}\right)=I_{i}, R\left(t_{i}^{*}\right)=R_{i}, S\left(t_{i}^{*}\right)=N_{i}-I_{i}-R_{i} \\
N_{i}=S+I+R
\end{gathered}
$$

In [5, 9] the set of differential equations (1)-(3) was solved by introducing the function

$$
V(t)=I(t)+R(t)
$$

corresponding to the number of victims or the cumulative number of cases. The corresponding analytical formulas for this exact solution; the saturation levels $S_{i \infty} ; V_{i \infty}=N_{i}-S_{i \infty}$ (corresponding the infinite time moment) and the final day of the $i$-th epidemic wave (corresponding the moment of time when the number of persons spreading the infection will be less than 1) can be found in [5, 9]. 
medRxiv preprint doi: https://doi.org/10.1101/2021.05.27.21257929; this version posted June 1, 2021. The copyright holder for this preprint (which was not certified by peer review) is the author/funder, who has granted medRxiv a license to display the preprint in perpetuity. All rights reserved. No reuse allowed without permission.

For many epidemics (including the COVID-19 pandemic) we cannot observe dependencies $S(t), I(t)$ and $R(t)$ but observations of the accumulated number of cases $V_{j}$ corresponding to the moments of time $t_{j}$ provide information for direct assessments of the dependence $V(t)$. In the case of a new epidemic, the values of its parameters are unknown and must be identified with the use of limited data sets. For the second and next epidemic waves $(i>1)$, the moments of time $t_{i}^{*}$ corresponding to their beginning are known. Therefore the exact solution [5, 9] depend only on five parameters $N_{i}, I_{i}, R_{i}, v_{i}, \alpha_{i}$, when the registered number of victims $V_{j}$ is a random realization of its theoretical dependence (4).

The real number of COVID-19 cases is much higher than the number of laboratory-confirmed patients [5, 10-15], since many patients have no symptoms or make no tests. If we assume, that data set $V_{j}$ is incomplete and there is a constant coefficient $\beta_{i} \geq 1$, relating the registered and real number of cases during the $i$-th epidemic wave:

$$
V\left(t_{j}\right) \cong \beta_{i} V_{j}
$$

then the number of unknown parameters increases by one. The values $V_{j}$, corresponding to the moments of time $t_{j}$, the exact solution $[5,9]$ and relationship (5) can be used to find the optimal values of the parameters $\alpha_{i}, \beta_{i}, N_{i}, v_{i}, I_{i}, R_{i}$ providing the maximum value of the correlation coefficient $r_{i}$ (see details in $[5,16])$.

\section{Results}

First we have calculated the optimal vales of parameters for the third wave of the COVID-19 pandemic in Qatar assuming that the dataset $V_{j}$ and $t_{j}$ reflects the real number of cases (i.e., we supposed that $\beta_{3}=1$ ). The results are shown in Table 2 (third column). The last column of the Table 2 represents the characteristics of the second wave calculated in [3] for $\beta_{2}=1$. It can be seen that the optimal values of parameters $N_{i}, v_{i}, \alpha_{i}$ and the final sizes $V_{i \infty}$ are rather different for the second an third pandemic waves in Qatar (see last two columns in Table 2), but the estimations of average time of spreading the infection $1 / \rho_{i} \approx 3.9$ days and the epidemic duration are very close. The corresponding SIR curves are shown in Fig. 1 by black (wave $2, \beta_{2}=1$ ) and red (wave $3, \beta_{3}=1$ ) colors. Solid lines represent the number of victims $V(t)=R(t)+I(t)$, dashed lines - the number of infectious persons $I(t)$ and dotted lines - the derivatives

$$
\frac{d V}{d t}=\alpha_{i} S I
$$


medRxiv preprint doi: https://doi.org/10.1101/2021.05.27.21257929; this version posted June 1, 2021. The copyright holder for this preprint (which was not certified by peer review) is the author/funder, who has granted medRxiv a license to display the preprint in perpetuity. All rights reserved. No reuse allowed without permission.

Equation (6) follows from (2)-(4) and yields a theoretical estimation of the average daily number of new cases which can be calculated by numerical differentiation of the smoothed accumulated number of cases

$$
\bar{V}_{i}=\frac{1}{7} \sum_{j=i-3}^{j=i+3} V_{j}
$$

as follows:

$$
\left.\frac{d \bar{V}}{d t}\right|_{t=t_{i}} \approx \frac{1}{2}\left(\bar{V}_{i+1}-\bar{V}_{i-1}\right)
$$

Values of the derivative (8) are shown in Fig. 1 by blue crosses and illustrate that the experimental and theoretical estimation for the second epidemic wave (eq. (6), dotted black line) started to deviate after January 16, 2021. At the end of March 2021 there was a sharp increase of the averaged daily number of new cases. In April 2021 derivative (8) was close to the theoretical estimation (6) for the third wave (compare crosses and the red dotted line in Fig. 1).

\begin{tabular}{|c|c|c|c|}
\hline \multirow{2}{*}{ Characteristics } & $\begin{array}{c}\text { Invisible wave 3, } \\
i=3, \\
\beta_{3}=5.308\end{array}$ & $\begin{array}{c}\text { Visible wave 3, } \\
i=3, \\
\beta_{3}=1\end{array}$ & $\begin{array}{c}\text { Visible wave 2, [3] } \\
i=2, \\
\beta_{2}=1\end{array}$ \\
\hline $\begin{array}{c}\text { Period taken for } \\
\text { calculations, } T_{c i}\end{array}$ & April 25 - May 8, 2021 & April 25 - May 8, 2021 & December 11-24, 2020 \\
\hline$I_{i}$ & $15,895.4703455678$ & $2,993.09405674162$ & 581.6852057918 \\
\hline$R_{i}$ & $1,057,266.11194015$ & $199,185.048800401$ & $140,084.171937066$ \\
\hline$N_{i}$ & $3,102,717.088$ & 571,480 & 343,800 \\
\hline$v_{i}$ & $2,137,169.15821761$ & $388,684.616416235$ & $203,678.101450066$ \\
\hline$\alpha_{i}$ & $1.18748428868345 \mathrm{e}-07$ & $6.52942943554382 \mathrm{e}-07$ & $1.26938469796243 \mathrm{e}-06$ \\
\hline$\rho_{i}$ & 0.253785479764225 & 0.253788877557122 & 0.258545865290753 \\
\hline $1 / \rho_{i}$ & 3.94033575494167 & 3.94028300068005 & 3.86778569781199 \\
\hline$r_{i}$ & 0.999979810302661 & 0.99997979869081 & 0.999943364258809 \\
\hline$S_{i \infty}$ & $1,866,781$ & 338,877 & 188,661 \\
\hline$V_{i \infty}$ & $1,235,936$ & 232,603 & 155,139 \\
\hline Final day of the & March 14, 2022 & January 18, 2022 & January 16, 2022 \\
\hline epidemic wave & & & \\
\hline
\end{tabular}

Table 2. Calculated optimal values of SIR parameters and other characteristics of the second and third pandemic waves in Qatar. 
medRxiv preprint doi: https://doi.org/10.1101/2021.05.27.21257929; this version posted June 1, 2021. The copyright holder for this preprint (which was not certified by peer review) is the author/funder, who has granted medRxiv a license to display the preprint in perpetuity.

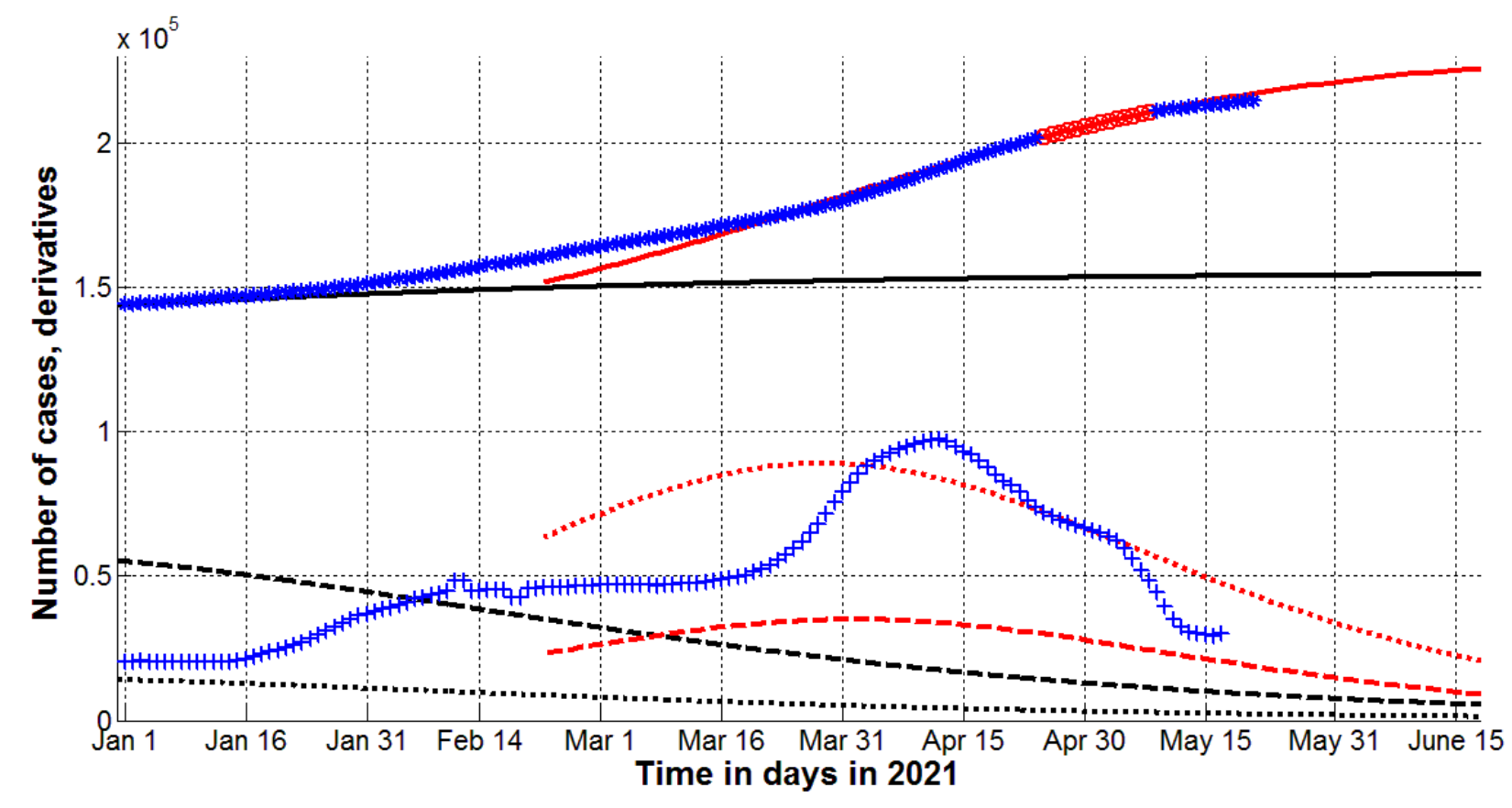

Fig. 1. Visible second (black, [3]) and third (red) pandemic waves in Qatar. SIR simulations (lines) calculated at $\beta_{i}=1$.

Numbers of victims $V(t)=I(t)+R(t)$ - solid lines; numbers of infected and spreading $I(t)$ multiplied by 10 - dashed; derivatives $d V / d t$ (eq. (6)) multiplied by 100 - dotted. Markers show accumulated numbers of laboratory-confirmed cases $V_{j}$ (from Table 1 and [3]) and derivatives. Red "Circles" correspond to the accumulated numbers of cases taken for calculations of the third wave (during period of time $T_{c 3}$ ); blue "stars" - number of cases beyond $T_{c 3}$. "Crosses" show the first derivatives (eq. (8)) multiplied by 100 .

Blue "stars" in Fig. 1 show the laboratory-confirmed cases $V_{j}$ (from Table 1 and corresponding Table in [3]) used only to check the results of calculation (in comparison with red "circles" corresponding to values taken for SIR simulations of the third epidemic wave in Qatar). It can be seen that the registered number of cases deviates from the theoretical curve for the second wave (compare the black line and "stars" in Fig. 1). The $V(t)=I(t)+R(t)$ curve for the third wave (calculated with the use of fresher dataset) is in good agreement with the accumulated number of cases confirmed after midMarch 2021 (compare the red line and “stars” in Fig. 1).

Assuming that the dataset $V_{j}$ does not reflect the real number of cases, we have calculated the optimal value of the visibility coefficient $\beta_{3}=5.308$ in relationship (5) and other optimal vales of parameters for the third wave of the COVID-19 pandemic in Qatar. The results are shown in Table 2 (second column). It can be seen that the correlation coefficient for the invisible wave 3 is higher than for its visible part. There is a huge difference in the optimal values of parameters $N_{i}, v_{i}, \alpha_{i}$ and the final sizes $V_{i \infty}$; large difference in the epidemic duration, but the estimations of average time of spreading the infection $1 / \rho_{i} \approx 3.9$ days are very close (compare second and third column in Table 2).

Red lines in Fig.2 represent the SIR curves for the invisible dynamics of the third epidemic wave in Qatar. Solid line shows the number of victims $V(t)=R(t)+I(t)$, dashed line - the number of infectious 
medRxiv preprint doi: https://doi.org/10.1101/2021.05.27.21257929; this version posted June 1, 2021. The copyright holder for this preprint

(which was not certified by peer review) is the author/funder, who has granted medRxiv a license to display the preprint in perpetuity. All rights reserved. No reuse allowed without permission.

persons $I(t)$ multiplied by 10 and dotted line - the derivative (6) multiplied by 100 . The accumulated numbers the laboratory-confirmed cases $V_{j}$ (shown by blue "stars" and red "circles") are much lover than the theoretical estimation of real number of cases $V(t)=R(t)+I(t)$ (shown by the solid red line).

To check the reliability of the method and the results of calculations the accumulated number of laboratory-confirmed cases $V_{j}$ (listed in Table 1) was smoothed with use of formula (7) and corresponding values $\beta_{3} \bar{V}_{i}$ are shown by the blue line. It can be seen that theoretical estimation (the red line) is very close the recorded number of cases multiplied by the optimal value of the visibility coefficient $\beta_{3}=5.308$. The values of the derivative of the smoothed accumulated number of laboratoryconfirmed cases (calculated with the use of equations (7) and (8)) have been multiplied by the optimal value of the visibility coefficient $\beta_{3}=5.308$ and shown in Fig. 2 by blue crosses which are close to the theoretical dotted line in April 2021.

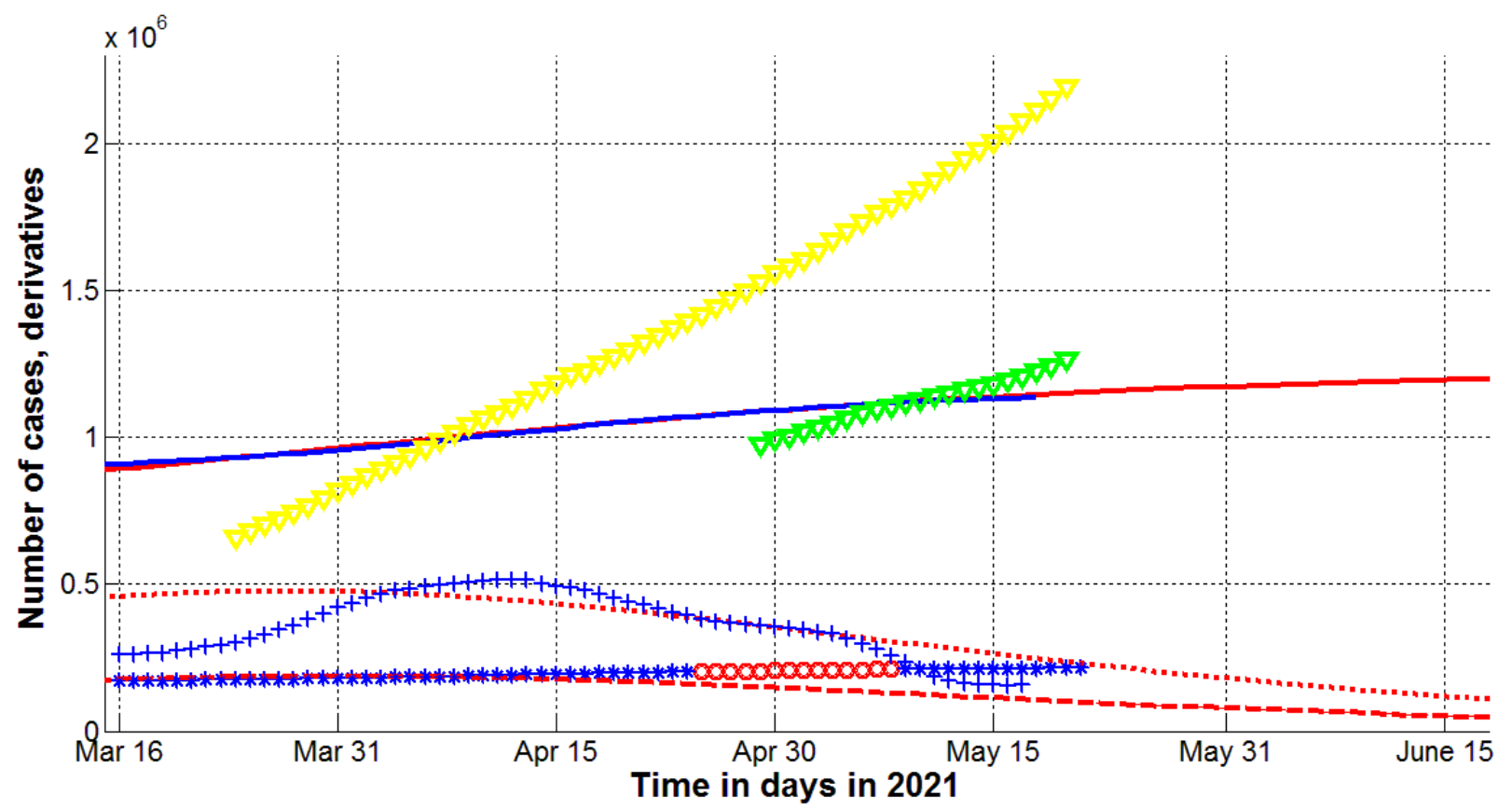

Fig. 2. Real sizes of the third pandemic wave in Qatar for the calculated optimal value of the visibility coefficient $\beta_{3}=5.308$. SIR simulations (red lines), numbers of vaccinations (yellow) and vaccinated persons (green).

Numbers of victims $V(t)=I(t)+R(t)$ - solid lines; numbers of infected and spreading $I(t)$ multiplied by 10 - dashed; derivatives $d V / d t$ (eq. (6)) multiplied by 100 - dotted. Markers show accumulated numbers of laboratory-confirmed cases $V_{j}$ (from Table 1 ) and derivatives. Red "Circles” correspond to the accumulated numbers of cases taken for calculations of the third wave (during period of time $T_{c 3}$ ); blue "stars" - number of cases beyond $T_{c 3}$. "Crosses" show the first derivatives (eq. (8)) multiplied by $100 \beta_{3}$. The blue line represents smoothed accumulated number of laboratory-confirmed cases (7) multiplied by $\beta_{3}$. 
medRxiv preprint doi: https://doi.org/10.1101/2021.05.27.21257929; this version posted June 1, 2021. The copyright holder for this preprint

(which was not certified by peer review) is the author/funder, who has granted medRxiv a license to display the preprint in perpetuity.

\section{Discussion}

The mass vaccination started in Qatar in late December 2020. The corresponding numbers of vaccinated people $S_{j}$ and vaccinations $Q_{j}$ are shown in Fig. 2 by "green" and "yellow" markers, respectively. Despite the relatively rapid rate of vaccination (in May 2021, the number of fully vaccinated people $Q_{j}-S_{j}$ approached half of the population), Qatar experienced the new wave of pandemics with a sharp increase in the number of patients in March-April 2021 (see blue "crosses” in Fig. 1). According to the forecast of the previous second wave (made in [3] using data before vaccination), the number of cases of should stabilize rapidly in 2021 (see the black solid line in Fig. 1). We will probably see the effect of vaccination only in June 2021. At least the latest data on the daily number of new cases have already become less than the theoretical estimates for the third wave (compare "blue" crosses and red dotted lines in Figs. 1 and 2).

The calculated coefficient of epidemic visibility $\beta_{3}=5.308$ for Qatar correlates with the values $\beta_{9}=4.1024$ and $\beta_{10}=3.7$ obtained in [5] for the ninth and tenth epidemic waves in Ukraine and the results of random testing in two kindergartens and two schools in the Ukrainian city of Chmelnytskii [15] which revealed the value 3.9. The total testing in Slovakia (65.5\% of population was tested on October 31 - November 1 , 2020) revealed a number of previously undetected cases, equal to about $1 \%$ of the population [13]. On November 7 next $24 \%$ of the population was tested and found $0.63 \%$ of those infected [14]. According to the WHO report at the end of October, the number of detected cases in Slovakia was also approximately $1 \%$ of population [17].

Ignoring information about the large number of unreported cases can lead to incorrect recommendations for quarantine restrictions and overly optimistic forecasts of the COVID-19 pandemic duration. For example, the information about the real dependence $I(t)$ is important to estimate the probability of meeting an infected person with the use of simple formula, [18]:

$$
p(t)=\frac{I(t)}{N_{p o p}}
$$

where $N_{p o p}$ is the volume of population. As of the end of May, 2021 the theoretical estimation yields the value $I \approx$ of 10,000 (see the dashed line in Fig. 2 ). Then the probability $p$ can be estimated as 0.0034 for Qatar. If only officially registered cases are taken into account, the corresponding probability will be approximately 5.3 times lower.

If current trends continue, new cases in Qatar will cease to be registered in January 2022 (see the third column in Table 2). But the invisible cases will continue for another two months (see the second column in Table 2). During this long period, new strains of the coronavirus may emerge and cause a new epidemic wave, which will be unexpected, as the visible part of the epidemic seemed to have been overcome. 
medRxiv preprint doi: https://doi.org/10.1101/2021.05.27.21257929; this version posted June 1, 2021. The copyright holder for this preprint (which was not certified by peer review) is the author/funder, who has granted medRxiv a license to display the preprint in perpetuity. All rights reserved. No reuse allowed without permission.

\section{Conclusions.}

The application of generalized SIR model to the new COVID-19 pandemic wave in Qatar demonstrated once more its effectiveness in predictions of epidemic dynamics and estimations of the vaccination efficiency. The parameter identification procedure allowed calculating the coefficients of data incompleteness (approximately 5.3 in the end of April 2021). New simulations with the use of fresher datasets are necessary to update the estimation of the vaccination efficiency in Qatar. Probably, real sizes of the pandemic in other countries are also much large than the number of registered cases. Thus reassessments of the COVID-19 pandemic dynamics are necessary, to avoid new unexpected waves.

\section{Acknowledgements}

The author is grateful to Oleksii Rodionov for his help in collecting and processing data.

\section{References}

1. Ahmed E. Fahmya, Mohammed M. El-desoukya, Ahmed S.A. Mohamed. Epidemic Analysis of COVID-19 in Egypt, Qatar and Saudi Arabia using the Generalized SEIR Model. MedRxiv. Posted August 22, 2020. Doi: https://doi.org/10.1101/2020.08.19.20178129

2. Ryad Ghanam, Edward L. Boone, Abdel-Salam G. Abdel-Salam. SEIRD MODEL FOR QATAR COVID-19 OUTBREAK: A CASE STUDY. Posted 26 May 2020. arXiv:2005.12777v1

3. Nesteruk I., Benlagha N. PREDICTIONS OF COVID-19 PANDEMIC DYNAMICS IN UKRAINE AND QATAR BASED ON GENERALIZED SIR MODEL. Innov Biosyst Bioeng, 2021, vol. 5, no. 1, pp. 37-46. DOI: 10.20535/ibb.2021.5.1.228605 http://ibb.kpi.ua/article/view/228605

4. COVID-19 Data Repository by the Center for Systems Science and Engineering (CSSE) at Johns Hopkins University (JHU). https://github.com/owid/covid-19-data/tree/master/public/data

5. Nesteruk I. Visible and real sizes of new COVID-19 pandemic waves in Ukraine. Innov Biosyst Bioeng, 2021, vol. 5, no. 2, pp. 85-96. DOI: 10.20535/ibb.2021.5.2.230487

http://ibb.kpi.ua/article/view/230487

6. Kermack WO, McKendrick AG. A Contribution to the mathematical theory of epidemics. J Royal Stat Soc Ser A. 1927;115:700-21.

7. Murray JD. Mathematical Biology I/II. New York: Springer; 2002.

8. Langemann D, Nesteruk I, Prestin J. Comparison of mathematical models for the dynamics of the Chernivtsi children disease. Mathematics in Computers and Simulation. 2016;123:68-79. DOI: 10.1016/j.matcom.2016.01.003

9. Nesteruk I. COVID19 pandemic dynamics. Springer Nature, 2021, DOI: 10.1007/978-981-33-6416-5

10. https://www.scmp.com/news/china/society/article/3076334/coronavirus-strange-pneumonia-seenlombardy-november-leading 
medRxiv preprint doi: https://doi.org/10.1101/2021.05.27.21257929; this version posted June 1, 2021. The copyright holder for this preprint (which was not certified by peer review) is the author/funder, who has granted medRxiv a license to display the preprint in perpetuity. All rights reserved. No reuse allowed without permission.

11. Frankfurter Allgemeine. https://m.faz.net/aktuell/sport/mehr-sport/militaerweltspiele-2019-inwuhan-damals-schon-corona-faelle-16758894.html

12. Weinberger DM et al. Estimating the early death toll of COVID-19 in the United States. [Preprint.] MEDRXIV, 2020 Apr. https://doi.org/10.1101/2020.04.15.2006643

13. https://edition.cnn.com/2020/11/02/europe/slovakia-mass-coronavirus-test-intl/index.html

14. https://www.voanews.com/covid-19-pandemic/slovakias-second-round-coronavirus-tests-drawslarge-crowds

15. https://podillyanews.com/2020/12/17/u-shkolah-hmelnytskogo-provely-eksperyment-ztestuvannyam-na-covid-19/

16. Nesteruk I. Procedures of Parameter Identification for the Waves of Epidemics. In book: COVID19 Pandemic Dynamics, Springer Nature, 2021. DOI: 10.1007/978-981-33-6416-5_10. https://link.springer.com/chapter/10.1007\%2F978-981-33-6416-5_10

17. World Health Organization. "Coronavirus disease (COVID-2019) situation reports". https://www.who.int/emergencies/diseases/novel-coronavirus-2019/situation-reports/.

18. Nesteruk I. Classical SIR Model and the Exact Solution of Differential Equations . In book: COVID-19 Pandemic Dynamics, Springer Nature, 2021. DOI: 10.1007/978-981-33-6416-5_4. https://link.springer.com/chapter/10.1007\%2F978-981-33-6416-5_4 